\title{
PJIEE
}

Premise: Journal of English Education and Applied Linguistics

https://fkip.ummetro.ac.id/journal/index.php/english

Milaningrum and Rahmawaty

\section{DEVELOPING ENGLISH MODULE FOR HOSPITALITY \\ STUDENTS USING INQUIRY-BASED LANGUAGE LEARNING IN BALIKPAPAN STATE POL YTECHNIC}

By

Elisabeth Milaningrum

ORCID ID: https://orcid.org/0000-0003-3730-1141

elisabeth.milaningrum@poltekba.ac.id

Patria Rahmawaty

patria.rahmawaty@poltekba.ac.id

Balikpapan State Polytechnic, East Kalimantan

Abstract:

This research is aimed at developing the existing English module for hospitality students to fulfill the students' needs in learning English using inquiry-based language learning at Balikpapan State Polytechnic. This research was conducted in the second semester of hospitality students at Balikpapan State Polytechnic. The research methodology used in this research was a research and development $(R \& D)$ for developing supplementary existing English module for hospitality students using IBLL. There are two stages of $R \& D$ study: (1) exploration stage which consists of library research, document analysis, and needs analysis. The purpose of the exploration stage is to find out the weaknesses of the existing English module by conducting documents analysis and to find out the students' need towards English materials by conducting an interview and delivering questionnaire. The result of reveals as follows: (a) the students need ESP (English for Specific Purposes) materials; $(b)$ the contents of the existing module are too general, only focus on TOEFL preparation and do not correspond with students' need and integrated English skills; (c) the procedure of the existing module only focus on lecturer center; and (2) development stage which is purposed to design the supplementary existing English module through several processes: (a) designing prototype based on the result of exploration stage; (b) experts validation; (c) trying out the prototype; (d) final revision. The data was taken from expert validation form, questionnaire, focus group discussion (FGD), and classroom observation. The data was analyzed by using an interactive method. The result shows that supplementary existing English module for Hospitality student is suitable to use in higher vocational education.

Keywords: English for hospitality, Inquiry-based language learning, Needs analysis, Supplementary English Module

\section{INTRODUCTION}

Current perspective in education proposes an autonomous in the learning process in order to shape creative and autonomous individual learner Liaw, Huang and Chen 
(20017). It is line with the recent studies on related developing English material for EFL students using Inquiry-based learning presented that through inquiry-based learning when developing English material which is integrated with technology into the curriculum can empower EFL students to improve linguistic skills, learn different perspectives on a topic, different cultural aspects, and develop social skills.

It also keeps students motivated and offers them more opportunities to construct knowledge under the principle of Zonal Proximal Device (ZPD) as reported in Snodin (2013). As a result of the related research about developing English material using inquiry-based learning shows that students have more contact with the target language in real life situations, increase the students' critical thinking skills, and have an opportunity to make connections with the outside world, visualize complex concepts. Since the role of IBBL is more active, through personal involvement students remember better what they do and acquire the foreign language in a similar way they did with the first one.

However, based on the result of pre-observation of existing English module for hospitality students that have used in Balikpapan State Polytechnic shows: 1) the teaching material existing English module only discuss about TOEFL preparation; 2) the activities on existing English module focus on students' reading comprehension meanwhile the goal of higher vocational students are creating students to master specific skills. The English module should provide various activities which ask students to practice their language using integrated skill that consists of reading, listening, speaking, and writing; 3) there are no language expression materials in the conversation and do not complete with speaking activity; 4) the procedure teaching methodology of existing English module are unclear.

Based on the result of the interview with some stakeholder in the hospitality industry, they agree that content of the existing English module is not appropriate with students' need in hospitality and do not accommodate students to use language in the real context of hospitality field. In the other hand, the hospitality lecturer also said that by having appropriate materials, it will help students in understanding communicative material. Therefore, this study focuses on Developing English Module For Hospitality Students Using Inquiry-Based Language Learning in Balikpapan State Polytechnic. This study aim is developing the existing English module for hospitality students to fulfill the students' needs in learning English using

Premise Journal Vol. 8 No 1, April 2019, e-ISSN: 2442-482x, p-ISSN: 2089-3345, page 1-16 Copyright@2019by PJEE 
inquiry-based language learning at Balikpapan State Polytechnic. Learning process in Balikpapan State Polytechnic as a higher vocational education focuses on developing specific skills to the trainee of students' professional quality as well as strengthens students' English language application ability and the actual communication ability. It is expected that the students will be skillful and competent to enter the real working field soon after graduating. English is considered as an important part for supporting higher vocational to be able to work and compete not only in the national and multinational company but also an international company.

It is supported with the demography location in Balikpapan that is famous with the oil city, therefore, there are many multinational and international company surrounded in Balikpapan. Moreover, it gives more chance for graduation especially in higher vocational education to fulfill the void employees. To gain this goal, the English teaching-learning process in Balikpapan State Polytechnic is expected the focus on developing communicative competence. It is to enable the students to communicate in the target language appropriately in both speaking and writing, to support their vocational competence in a certain major. Based on the need analysis, Balikpapan State Polytechnic as higher vocational education should use ESP (English for Specific Purposes) that is suitable with the specific major skills.

In support of this condition, a theory has proposed that this goal is positive. Zhu (2012, p. 87) states that one of the goals of teaching in higher vocational education is to use English to describe the professional field of the working environment, working rules, and working procedures. Since the goal of vocational education is preparing students to get a job. Therefore, they should have specific materials which are appropriate with their program. It is supported by Richards (2001) who says that the content of ESP course is determined by the basic skills due to the learners' purpose; the grammatical selection including the vocabularies and grammatical patterns and the language functions; topics and themes related to the learners' purposes, and the needs of communication. A similar sense is also implied (Richard \& Rodgers, 2001).

However, after the researcher made analysis English module that has used to teach hospitality students, it can be seen that this module is not suitable with the goal of learning process in higher vocational education which does not contain about integrated four English skill to produce communicative skill using ESP material for

Premise Journal Vol. 8 No 1, April 2019, e-ISSN: 2442-482x, p-ISSN: 2089-3345, page 1-16 Copyright@2019by PJEE 
hospitality and do not suitable with the stakeholder's need in hospitality industry. The materials in the English module for hospitality students are too general and more focus on TOEFL preparation in reading comprehension. The English materials are not specific enough for higher vocational students and it is not based on the students' need, therefore, the English materials cannot facilitate students to use and expand their knowledge and skill in their future working place.

To overcome those problems, the researcher used R \& D study to develop an English module for hospitality students of Balikpapan State Polytechnic as one of the media in the teaching-learning process. The goals of teaching process can be achieved and it will be beneficial for hospitality students by using appropriate English module. Ellis and Johnson (1994) explain that teaching materials should be useful for students, relevant to the student needs, stimulate students' curiosity to learn, and consist of activities and tasks which worth to them. Therefore, it is needed for English lecturer in higher vocational education to use ESP (English for Specific Purposes) in the teaching process. The advantages of having ESP materials in English module are: 1) the materials focus on purposeful learning, and 2) the materials stimulate learners as an active processor of information and to make sense of the information by imposing a meaningful interpretation or pattern on it.

Teaching methodology also plays an important role in designing a module because by using an appropriate methodology, the module will have clear steps which can help lecturer and students to maximize the use of the module. Inquirybased language learning (IBLL) is an appropriate methodology because it focuses on the student center. IBLL provides some steps that emphasize students to involve and to be active in the learning process, therefore, the students have an opportunity to practice and expand their language. According to Fauziati (2014: 160), there are five steps in IBLL: 1) engagement. Students are asked to observe their surroundings. They may observe objects, events, or any other phenomenon; 2) exploration. Students are asked to explore what they have observed before. Here, students are stimulated to make some questions related to object; 3) explanation. The lecturer gives an explanation to students; 4) elaboration. Students worked with their friends to try to practice what they have learned. The role of lecturer at this stage is as a facilitator. She/he observers and checks students; 5)

Premise Journal Vol. 8 No 1, April 2019, e-ISSN: 2442-482x, p-ISSN: 2089-3345, page 1-16 Copyright@2019 by PJEE 
evaluation. Students individually do some tasks to check their understanding of materials.

This current research was intended to find out the quality of existing module used to teach English for hospitality students at Balikpapan State Polytechnic based on the students' need and then developing English supplementary module for hospitality students based on inquiry-based language learning (IBLL). The study tries to answer the research questions below:

1. How is the quality of the existing English module for hospitality students in Balikpapan State Polytechnic?

2. How is the development of English materials for hospitality student based on inquiry-based language learning?

\section{METHODOLOGY}

\section{Design}

This research methodology used to research and development study under the concept Borg and Gall (Gall, Gall, \& Borg, 2003, p. 772) that R \& D is an industry-based development model which used to design new products and procedures, which they are systematically field-tested or tried out, evaluated, revised, and refined until they meet specified criteria of effectiveness, quality, or similar standard. Therefore, it can be concluded that $\mathrm{R} \& \mathrm{D}$ is a process of research to design new products and procedures through systematically steps to achieve the specified criteria and quality. The systematical process is field tested or tries out, evaluating, revising, and refining.

There are two steps in the R \& D process: 1) exploration stage. It consists of library research, needs analysis, and book analysis; 2) development stage. It consists of designing prototype, expert validation, trying out the prototype, and final revision.

The data was taken by using a questionnaire, interview, classroom observation, expert judgment sheet, document analysis, and focus group discussion (FGD). Then the data were analyzed by using the Interactive Model by Miles and Huberman (2014). There are three steps in analyzing the data: 1) data reduction; 2)data display, and 3) drawing the conclusion.

Premise Journal Vol. 8 No 1, April 2019, e-ISSN: 2442-482x, p-ISSN: 2089-3345, page 1-16 Copyright@2019 by PJEE 


\section{Participants}

The subject of this research is the second semester of hospitality students. This research used one class as the ESP research subject that is students in the hospitality department at room division major in Balikpapan State Polytechnic.

\section{Instrument and Source of Data}

This research used some instruments to develop the English module for hospitality students that can be decided into two stages they are: exploration stage and development stage. In the exploration stage, the researcher used a questionnaire, and documentation in order to know about the students' need and also know about the quality of the existing book. For the development stage that consists of some activities such as: developing draft or prototype, evaluating by expert judgment and revising the draft of the prototype used questionnaire. Then, while conducting Forum Group Discussion (FGD) and interviews used a list question for FGD and interview as an instrument, and classroom observation used documentation. While the instrument used in developing the final draft or prototype was a quantitative questionnaire and for evaluating the result of prototype used questionnaire either test or non-test in order to know the progress result of developing the English module.

\section{How those instruments are validated}

There is some instrument that used in this research such as questionnaire, list of interview questions, documentation. In order to validate the question of the questionnaire used normality Lilliefors method and Barlet test to validate the homogeneity. The list of interview questions and FGD used the criteria from Cunningsworth (1995) and hospitality stakeholders.

\section{Data Collecting Technique}

A technique of collecting data is a process of gaining data in order to find the answer or the result of the research. In the exploration stage, the researcher will collect the data taken from interviews, document analysis, and questionnaire. The researcher used a semi-structured interview in order to gain deep information

Premise Journal Vol. 8 No 1, April 2019, e-ISSN: 2442-482x, p-ISSN: 2089-3345, page 1-16 Copyright@2019 by PJEE 
related to this research. In document analysis, the researcher analyzed the existing English module for hospitality students in order to find the quality of that module. Then, the researcher delivered a questionnaire to hospitality students after conducting try out. It is aimed to know the students' needs.

In the development stage, the researcher started to develop a prototype or draft. That prototype or draft evaluated by the expert judgment in order to find the quality of it and to find out whether or not the prototype or draft met the specific needs. Besides, the prototype or draft also tried out at the campus. There are several ways of collecting data from the data sources, they are: interviews, observations, questionnaire, Forum Group

Discussion (FGD), and expert judgment sheets. The researcher conducted a semi-structured interview. The observation did by the researcher. In this way, the observer observed the implementation of proposed teaching materials in the classroom; make field notes for all activities in the teaching and learning process. Questionnaire delivered to hospitality students after conducting try out. It was aimed to know the students' perspective towards proposed English teaching materials. Then, Forum Group Discussion (FGD) did after conducting try out. The participants of FGD were some hospitality students, English lecturers, the researcher and stakeholder of the hospitality industry. The purpose is to know the quality of the proposed English teaching module. And the last step of collecting the data in development stage was an expert judgment sheet. After developing a draft or prototype, evaluating draft or prototype were judged by some experts in order to know the quality of the draft or prototype. Besides, it also aimed to know whether the draft or prototype has met with students needs or not.

\section{Data Analysis Technique}

To analyze the data, the researcher used the Interactive Model as suggested by Miles and Huberman (2014). In the exploration stage, the process includes the following steps: data reduction, data display, and conclusion. The result of data analysis presented in the form of describing existing problems and interpreting them into general conclusion. In the development stage, the quantitative and qualitative method used to analyze the data. The data taken from observations, interviews, and FGD analyzed by using a qualitative method. Miles and Huberman 
(2014) suggest an interactive model analyze the data. The process includes three steps, they are data reduction, data display, and conclusion drawing. Then, the quantitative method was used to analyze the result of the questionnaire. The researcher used descriptive technique analyzing which means that the way of analyzing the data is to know the percentage only.

\section{RESULT AND DISCUSSION}

\section{Result}

The results of existing English module analyze show: 1) the aims of existing English module for hospitality students are too general and do not meet with the students' need. The aim of the existing English module for hospitality is emphasizing students to master tips and trick of TOEFL Preparation especially reading comprehension part. Meanwhile, the aim of higher vocational education is preparing students to master specific skills; therefore they need English materials specifically based on their skills major. As higher vocational education is needed to learn ESP (English for Specific Purposes) based on their major skills, therefore, each student hopefully can familiar with the ESP vocabularies/diction of their skills major; 2) the existing English module only provides two English skills: reading and writing. There is no integrated skill between four English skills during the teaching-learning process. Reading has the biggest part meanwhile writing have a small part. There is no listening and speaking activity on it. The existing module only concern on passive English which does not suitable with the output of hospitality students that should master about active English; 3) the existing English module only organized to achieve the high score of TOEFL without focus on the English fluency which is the most important thing in the hospitality field that will give service in hospitality field. In each exercise on the module only focuses to implement the tips and trick in TOEFL; 4) the existing English module is designed without concern with the stakeholder's need that is the hospitality industry. There is no existing authentic material that is relevant to the development of the hospitality field. 5) the teaching methodology that is used in existing English module only focus on lecturer center, therefore, each student does not have a chance to explore their competence in each topic and also never practice it to prepare their future working in the hospitality field.

Premise Journal Vol. 8 No 1, April 2019, e-ISSN: 2442-482x, p-ISSN: 2089-3345, page 1-16 
Moreover, the results of needs analysis show: 1) they need English for their future career in their working place especially to face foreign tourist that always increases in each year.; 2) they need English which is appropriate with their major skills because it can help and facilitate them in achieving their goals that have good capability either active English and passive English so that they can communicate with foreign guess in the hospitality field. It also can help them to figure out the situation of their future career; 3) the English materials should represent about skills in hospitality field and can be used in students' future working place; 4) the students need practice speaking especially about conversation in hospitality field and listening activity using various activities which facilitate them to understand the materials and to practice language.

After analyzing the existing book and students' need. The researcher designed a prototype product in order to get a better result and to know whether the prototype has met with the students need and can be tried out or not. The prototype is validated by the experts of ELT and stakeholder in the hospitality industry. The result shows the prototype can be tried out to hospitality students to get feasibility of the prototype. Try out was done twice. At the end of each tryout, focus group discussion (FGD) was conducted to get the detailed information towards the prototype and questionnaires were delivered at the end of try out in order to know the responses from students after learning by using the prototype. The results of try out show that the aims and contents of prototype correspond to students' need and it can be used as supplementary English module for hospitality students.

\section{Discussion}

Some of the preliminary researches have some similarities result with this research. Duren(2016) on his research about the effect of the inquiry-based learning approach on student's critical thinking skills has the findings which revealed that science and technology learning supported with the guided activities developed in line with the IBLL ( Inquiry Based Language Learning) approach that have significant effects on students' critical-thinking skills in science and technology courses. Moreover, according to Ramnarain (2018) states that teacher from the rural district have a positive attitude towards an inquiry in the teaching and learning of Physical

Premise Journal Vol. 8 No 1, April 2019, e-ISSN: 2442-482x, p-ISSN: 2089-3345, page 1-16 Copyright@2019 by PJEE 
Sciences, and recognize the benefits of inquiry, such as addressing learner motivation and supporting learners in the understanding of abstract science concepts.

According to Pamungkas (2016) that develop supplementary English module for automotive in vocational school and also Purbasari (2016) that designing English module for accounting students invocation school using IBBL which both of those research have similarity expert judgment that is developed materials are better than the previous module. It is line with this research about developing English module using Inquiry-based language learning (IBLL) for hospitality students that focus on the student center because IBLL provides some steps that emphasize students to involve and to be active in the learning process, therefore, the students have an opportunity to practice, expand their language, increase students' critical-thinking and stimulate students' motivation to learn enthusiastically.

English module for hospitality student is designed as a supplementary module for second-semester hospitality students in Balikpapan State Polytechnic. It is designed under IBLL that provides five steps of teaching, such as: Let's Explore, Let's Ask, Let's Work Together and Practice, and Progress Check. The beginning steps are "Let's Explore and Let's Ask". Those steps are used as warming up an activity that asks students to observe and explore their surroundings. They may observe pictures, video or bring their experiences to the teaching process. Those activities are used to motivate students and attract students' interest to learn before the teaching-learning process. Moreover, it also stimulates students' background knowledge and invites students to engage and involve in the learning process. It is supported by Brown (2001) that states the materials should be started from activity that aims to engage the students to the topic as warming up activity. The next step is "Let's Work Together and Practice". It consists of whole-class work, group discussion, pair work, teacher's talk, and small group. And the last step is "Progress Check" which consists of several questions that should be done by students individually in order to check students' comprehension towards materials. It is in line with Brown's procedure of teaching.

To get feasibility of the draft prototype, it is evaluated by experts, tried out to students, and revised. The final draft becomes the supplementary English module which is used by second-semester students of the hospitality department at room division major in Balikpapan State Polytechnic. The study tries to answer the 
research questions as follow: 1) The quality of existing English module, and 2) the development of an English module for hospitality students as supplementary English module for second-semester hospitality students. The findings show that the existing module has some weaknesses. Based on the good criteria module from Cunningsworth (1995). There are six criteria such as aims, design and organization, language content, skills, topics, and methodology.

1. Aims

It is not in line with the aims of the learning process at higher vocational education that should be specified using ESP based on each major skills to perform a particular job. Higher vocational students need to be prepared to enter the working field and should have some special abilities to support their knowledge.

2. Design and Organization

The design of the existing module is not matched with hospitality and the organization of the module is not completed by speaking assessments in making conversation based on the hospitality field and also it is not completed with audio for listening to practice their pronunciation.

3. Language Content

The language content in existing English module does not have the specific vocabulary in ESP for hospitality, pronunciation, expression and various grammar materials to support the goals of English for hospitality students.

4. Skills

The existing module should cover not only two skills that are reading and writing but also the four English skills and it should be provided with various integrated language skills activities which can help them learn English communicatively.

5. Topics

The existing English module does not represent students' future working place and also the material is not relevance with hospitality, therefore, it does not allow students to expand their knowledge and help students to face challenges of their future working place

6. Methodology

The methodology of the existing English module use the direct instruction

Premise Journal Vol. 8 No 1, April 2019, e-ISSN: 2442-482x, p-ISSN: 2089-3345, page 1-16 Copyright@2019 by PJEE 
method that is only focused on the lecturer center and also the procedure of the method are unclear.

After being tried out, the strength and weaknesses of the draft prototype are found. The strength will be explained as follows:

1. English module for Hospitality is completed with a speaking assessment that competed with some expressions and dialogues that are used in hospitality working field and also listening exercise completed by video and audio.

2. English module for Hospitality is designed using inquiry-based language learning which emphasizes to students center in the teaching-learning process.

3. English module for Hospitality contains materials which are suitable to student's need that is based on the future hospitality field and stakeholder's need in the hospitality field.

4. English for module Hospitality contains various activities which facilitate students to expand their knowledge and also can be taught in many ways of teaching.

Then the weaknesses of the draft prototype will be explained as follows:

1. The English lecturer should have the knowledge in hospitality by using spreading networking with stakeholder in hospitality working field to make the teaching material is updated with the development of tourism and hospitality field using authentic material.

2. English module for Hospitality contains the materials only use for secondsemester students in the hospitality department at room division major.

\section{CONCLUSION AND SUGGESTION}

\section{Conclusion}

After conducting research, it can be drawn the conclusion as follows:

1. The result of the exploration stage shows that the quality of the existing English module is not suitable for the students' hospitality need. The content of the book is too general while the students need more specific English materials based on hospitality major skill. They need English materials 
specifically for hospitality. Besides, the steps of the existing book do not represent the steps of inquiry-based language learning and only focus on the lecturer center. Therefore, the researcher decides to design the English supplementary English module for hospitality students at Balikpapan State Polytechnic based on inquiry-based language learning.

2. At the development stage, there are several steps that have been conducted by the researcher. The result of the development stage shows that the proposed English module for hospitality can be used as a supplementary module to teach English for hospitality students. There are some differences between the existing English module and the proposed module. The biggest differences are the content of the module. The existing module consists of general English materials while the proposed module consists of specific English materials related to hospitality. Besides, the proposed material is designed based on inquiry-based language learning while the existing book is not. Therefore, the supplementary English module for hospitality students at Balikpapan State Polytechnic can be used as supplementary English module in the hospitality department at room division major.

\section{Suggestion}

Based on the result of the research, there are some suggestions for a better future as follows:

1. As the higher vocational education, the English module should content about ESP (English for Specific Purposes) based on each major skills, therefore, the teaching material does not only focus on TOEFL preparation, event TOEFL is also an important thing to prepare working field because until now it is still used as an administrative requirement to measure the English competence in recruitment or campus hiring from some stakeholder except hospitality.

2. To make attractive learning process, it should integrate skill in each meeting activity between listening, reading, writing, and speaking skills based on the suitable ESP topic to make students are enthusiastic and not bored since the English learning process.

Premise Journal Vol. 8 No 1, April 2019, e-ISSN: 2442-482x, p-ISSN: 2089-3345, page 1-16 
3. There is update teaching material during the development of stakeholders' need in this case hospitality field and adapt to the renewable curriculum in higher vocational education.

\section{BIO-PROFILE}

Elisabeth Milaningrum, M.Pd is an English lecturer in Balikpapan State Polytechnic. She graduated her undergraduate program in English Education, Teachers Training and Education Faculty, Sebelas Maret University in 2011. Then, she continued her postgraduate program in the same department and university, graduated in 2013. She has published articles and presented papers on English language teaching, applied linguistics and research methodology either national or international conferences. She can be reached at elisabeth.milaningrum@poltekba.ac.id

\section{BIO-PROFILE}

Patria Rahmawaty, S.Psi., M.MPd.Psi is a lecturer and psychologist in Balikpapan State Polytechnic. She graduated her post-graduate program at Education Management Faculty, Islam Nusantara University Bandung in 2012. She has published articles and presented papers on psychology and education either national or international conferences. She can be reached at patria.rahmawaty@poltekba.ac.id 


\section{REFERENCES}

APA. (2010). Publication Manual of the American Psychological Association (6th ed.). Washington DC: American Psychological Association.

Brown,H.D. (2001).Teaching by principles. London: Longman.

Cunningsworth, Alan. (1995). Choosing your coursebook. Oxford: Heinemann.

Duran, Meltem. (2016). The Effect of The Inquiry-Based Learning Approach on

Student's Critical Thinking Skills. ISER journal Vol.12 No.12, doi:

10.12973/ urasia.2016.02311a

Fauziati, Endang. (2014). Methods of Teaching English as a Foreign Language

(TEFL): Traditional Method, Designer Method, Communicative Approach, And Scientific Approach. Solo: Era Pustaka Utama.

Gall, M. D., Gall, J. P., \& Borg, W. R. (2003). Educational Research: An Introduction (7th ed.). Boston, New York, San Francisco, Mexico, Montreal, Toronto: Pearson Educational Inc.

Liaw, S. S., Huang, H. M., \& Chen, G. D. (2007). Surveying instructor and learner attitudes toward e-learning. Computers \& Education, 49(4), 1066-1080.

Miles and Huberman. (2014). $3^{\text {rd }}$ Edition Qualitative Data Analysis. USA: Arizona State University.

Pamungkas, A. P. (2016). Developing a Set of Supplementary Learning Materials of Written Cycle for Students of Grade XI of Automotive Engineering at Vocational School. English Language Teaching Journal, 5(12).

Purbasari, A.Dita, (2016).Thesis: Materials Development for Accounting Students Based on Inquiry-Based Language Learning. Solo: UNS Press

Ramnarain, Umesh. (2018). Teacher beliefs and attitudes about inquiry-based learning in a rural school district in South Africa. SAJE Journal Vol.38 No. 1, doi: 10.15700

Richard, J. C., \& Rodgers, T. S. (2001). Approaches and Methods in Language Teaching (2nd ed.). Cambridge, USA: Cambridge University Press.

Richards, J.C. (2001). Curriculum development in language teaching. Cambridge: Cambridge University Press.

Premise Journal Vol. 8 No 1, April 2019, e-ISSN: 2442-482x, p-ISSN: 2089-3345, page 1-16

Copyright@2019 by PJEE 
Snodin, N. S. (2013). The effects of blended learning with a CMS on the development of autonomous learning: A case study of different degrees of autonomy achieved by individual learners. Computers \& Education, 61, p.209-216.

Zhu, Huaxiao. (2012). Discussion about Vocational English Teaching Reform. International Conference on Education Technology and Management Engineering Journal Vol. $16(1)$.

Premise Journal Vol. 8 No 1, April 2019, e-ISSN: 2442-482x, p-ISSN: 2089-3345, page 1-16 Copyright@2019by PJEE 